\title{
REFORMING OF THE UKRAINIAN EDUCATIONAL SYSTEM IN THE CONTEXT OF TRANSBORDER INTEGRATION INTO THE WORLD ACADEMIC SPACE
}

\section{S. Tolochko}

У даній статті проаналізовано досвід формування світового освітнього простору в умовах транскордонної інтеграчії. Розглянуто світову практику розв'язання освітніх проблем, виявлено сутнісні характеристики інтеграційних прочесів для подальшої імплементації в освітній процес вітчизняної освітньої системи. Проаналізовано доповіді економічного форуму в Давосі, дослідження Міжнародної бізнесшколи INSEAD, Корнельського університету та Всесвітньої організації інтелектуальної власності, Римського клубу, звіт ООН «Індекси та показники людського розвитку», Світового освітнього форуму, неурядової організаціï Cambridge Assessment. Підтверджено, щзо реформування освітньої системи України в прочесі інтеграції у світовий академічний простір відбувається завдяки розробиі й упровадженні в освітньо-науковий прочес вітчизняних закладів освіти законодавчо-нормативної документації. Охарактеризовано проміжні результати вітчизняного профільного міністерства щэодо реформування освітньої системи Украӥни у світовий академічний простір: пріоритети на 2019 рік у діяльності з реформування освітньої системи України в контексті транскордонної інтеграцї та поточні плани - «То do list» перемін,-які упровадять у сферах освіти науки та інноватики. Зазначено, що ці завдання актуалізують зростання професійно-педагогічної компетентності викладачів $3 В О$ та ЗППО. Так, Типова освітня програма організачії і проведення підвищення кваліфікащії педагогічних пращівників закладами післядипломної педагогічної освіти у профілі базових компетентностей тренерів $і$ вчителів початкових класів включають такі: андрагогічну, професійно-педагогічну, соціально-громадянську, загальнокультурну, мовно-комунікативну, психолого-фасилітативну, підприємницьку та інформаційноицфрову. Визначено, щзо здійснений аналіз актуалізував ще одну важливу компетентність викладача науково-методичну,сформульовано ї̈ дефініцію в авторському баченні.

Досліджено проблеми кадрового забезпечення та трудової міграції в контексті сучасних глобалізаційних викликів і транскордонної інтеграчії Украӥни у світовий академічний простір та надано рекомендації щуодо їхнього вирімення

Ключові слова: світовий освітній простір, транскордонна інтеграчія, реформування, викладачі, професійно-педагогічна, науково-методична компетентність

\section{Introduction}

In the context of cross-border integration into the world academic space, lifelong learning is of particular importance, which creates prospects for continuing education and prolonged employment, and for professionals, who has higher education, to acquire a second, parallel, cross-specialty (mastering or updating competencies) or develop their skills (getting crosscompetencies), using opportunities of postgraduate education, which is ultimately a factor in preventing labor migration, and creating preconditions of staffing on the national labor market.

\section{Literature review}

Modern scientists' researches show a considerable interest to the problem of reforming the Ukrainian educational system in the context of cross-border integration into the world academic space and its further development in conditions of lifelong education. This, in its turn, actualizes the role of comparative studies, introduction and adaptation of optimal world standards into educational practices of national higher education institutions and postgraduate pedagogical education. Professional and pedagogical training becomes significant in this context, especially scientific and methodological training, competence of teachers as the main participants in the educational and scientific process and its constant updating, formation and development in the conditions of lifelong education.

Thus, according to all components of the Global Competitiveness Index - 2018, Ukraine's position is defined in [1], its position in the Global Innovation Index is specifies in $[2,3]$. Results of the UN report "Indices and Indicators of Human Development" are presented in [4]. Ukraine's place in the global rankings for the higher education competitiveness index is shown in [5]. Main requirements to the process and result of training for youth's "future awareness" formation are established in 
[6], and importance to integrate the best experience of leading educational systems is given in [7]. The importance of accessibility and effectiveness of education in cross-border integration is proved in [8]. The national educational policy in 2019 is named in [9], priorities in 2020 and the following years are announced in [10]. The structural-system analysis of the definition of modern key competences in the world and the countries of the European Union is presented in $[11,12]$. Theoretical and methodological foundations of forming the scientific and methodological competence for teachers in postgraduate pedagogical education are revealed in [13]. Conceptual and methodological bases of forming the teachers' postgraduate pedagogical education scientific and methodological competence are developed in [14]. The importance of lifelong learning in modern sustainable development strategies is detailed in [15]. The teachers' professional competence in the age of globalization in the world is analyzed in [16]. Recommendations on a common set of technological competencies for training teachers-candidates for the learning technology in the United States are given in [17]. Mathematics teacher's technological and pedagogical professional competences for the development of 21 st century student's skills is defined [18]. The application of situational training for postgraduate software course students is covered in [19]. The exploration of the mixed synthesis of literature on teaching qualitative research methods is presented in [20]. The diagnosis of the university's first-year teacher training program is covered in [21].

In spite of such specific attention to the problem of reforming the modern educational system of Ukraine and modernization innovations, the problem of forming, updating and developing the teachers' professional and pedagogical competence in the context of integration into the world academic educational space, science and innovation requires constant analysis.

\section{Purpose and objectives of the research}

The purpose of the research is a structural and system analysis of studying the experience of formation of the world educational space in the context of crossborder integration in order to ensure the introduction into the education system of Ukraine, including lifelong education in general and postgraduate pedagogical education in particular. were set:

To achieve this purpose, the following objectives

- to analyze the results of studies of interstate structures and non-profit international organizations and foundations, to study the experience of forming the world educational space in the context of cross-border integration;

- to consider the world practice of solving educational problems, to identify the essential characteristics of integration processes for further implementation into the educational process of the national educational system;

- to characterize interim results and current plans of the national line ministry as for reforming the Ukrainian education system into a global academic space in the context of lifelong education;
- to provide guidance as for solution of staffing problems and labor migration in the context of modern globalization challenges.

4. Theoretical and methodological aspects of substantiation of studying the experience of the world educational space formation in conditions of crossborder integration in order to ensure introduction into the Ukrainian education system

Cross-border integration, which is considered at the level of links between countries, covers most types of business activities, including the research and education sphere. The global academic space, accumulating the best achievements of national education systems, is increasingly influencing the formation and operation of the global market of scientific-education goods and services, contributing to the reform and modification of the systems of interconnections and dependencies between its participants. In this regard, the role of education and science has continued to grow steadily over the last three decades, which should accordingly be given due attention by country's governments to the process of reforming national education systems, including the purpose of ensuring the sustainable development and competitiveness of the countries on the world economic and financial markets. Experts estimate that nowadays, the global education industry, including costs on national education systems, is the second largest market after health care. The global value added, created by the knowledge- and technology-intensive industries, now makes about 30\% of world GDP, in the most developed countries the export share of commercial knowledge-intensive products exceeds one third, and the world volume of information is doubled daily [1].

The structural and system analysis of the definition of modern key competences in the world [11] and analysis of the European Union countries' experience in solving contemporary problems in education and science [12] have actualized the problem of implementation of the world practice in national education and science. Therefore, the society's sustainable development in Ukraine aims at introducing European standards and leadership in the world, economic growth with the use of resources to meet human needs while preserving the environment, protecting the interests of future generations, the need for a safe environment, etc. Lifelong learning in modern sustainable development strategies actualizes technological innovations that significantly expand the scope of internationalization of education: rapid improvement of the quality of knowledge, reorientation to the international level of interaction, integration into advanced production technologies and management strategies [15].

The Davos World Economic Forum annually publishes a number of reports exploring in details the wide range of global issues that it seeks to draw attention from stakeholders as part of its mission to improve the world. In addition to reporting on its key events and specific publications, such as the Global Competitiveness Report, the Global Risk Report and the Global Gender Gap Report, the Forum creates landmarks covering environment, education, specific industries and technologies [2]. 


\section{The results of the research}

For example, the 2018 Davos Economic Forum report used a new methodology that made it possible to take the full account of the impact of the Fourth Industrial Revolution on the economic development of the world. The updated index estimated 140 economies in the world according to 98 indicators, which are divided into 12 groups or drivers of productivity.

For each indicator, a scale from 0 to 100 was used, which indicated how close the economy was to an ideal state or was at the "border" of competitiveness (Table 1).

Table 1

Global Competitiveness Index (Ukraine's position on all parameter of the Index)

\begin{tabular}{|l|l|}
\hline 6. Qualification & 51 \\
\hline 6.01 Average duration of schooling & 74 \\
\hline 6.02 Coverage of staff training & 63 \\
\hline 6.03 Quality of training & 62 \\
\hline 6.04 Graduates' qualification & 55 \\
\hline 6.05 Digital skills & 54 \\
\hline 6.06 Convenience of finding qualified employees & 54 \\
\hline 6.07 Expected duration of schooling & 41 \\
\hline 6.08 Critical thinking in teaching & 32 \\
\hline 6.09 Number of teaching hours in elementary school & \\
\hline
\end{tabular}

Source: report The Global Competitiveness Index 2018

These tables show relatively good performance in the following components: number of working hours for primary school teachers, critical thinking in teaching, average duration of schooling, expected duration of schooling, and the convenience of searching for qualified staff. However, the second half of the rating contains the poorer indicators of the Ukrainian educational system, in author's opinion these are the quality of adult education, including postgraduate education, its organization and reform, namely: coverage of staff training, quality of professional training, graduates' qualification, digital skills. These data actualize the problem of teacher's professional competence as a participant in the educational and scientific process, in particular formation, development and further continuous modernization of his/her scientific and methodological competence.

Another index - the Global Innovation Index - is a survey of INSEAD, International Business School, Cornell University and the World Intellectual Property Organization, which analyzes the degree of innovation in infrastructure, education and entrepreneurship and creates rating. This year there are 126 countries in the rating [3]. Ukraine in the Global Innovation Index climbed from 50th place in 2017 to 43rd place in 2018, representing the best position for 12 years of the rating existence (Fig. 1)

In the context of our analysis, let us also focus on the Human Development Index - an index for the comparative assessment of poverty, literacy, education, average life expectancy, level of health protection, social security, longevity, ecology, level of crime, human rights and GDP per capita. The UN has published [4] a Human Development Indices and Indicators report, in which Ukraine ranks 88th among 189 countries. According to the UN rating, the human development index in Ukraine is 0.751 , life expectancy is 72 years, duration of schooling is 15 years, and average is 11.3 years. Compared to 2016 in 2017-2018 Ukraine did not report a progress in international human development ratings and remained at the same level. At the same time, experts have witnessed improvements in particular areas: access to information and communication, freedom of choice and personal freedom, as well as access to higher education. However, deterioration in personal safety and tolerance was found.

So, in Global Competitiveness Index Rankings: Higher Education (GCI - WEF) in 2017-2018 Ukraine fell by 2 positions compared to the last year and now ranks 35 th out of 137 . For the country's progress in the ratings of actual human capital indicators, radical reforms in the field of education and training should be undertaken, with a shift in emphasis on quality and the development of a system of lifelong learning for adults [5].

The main thesis of the 43rd report "Come on! Capitalism, short-sightedness, population and destruction of the planet» of the Club of Rome - an international public analytical centre, that brings together representatives of the world political, financial, cultural and scientific elite and seeks to actualize the global problems of humanity and nature - sounded as follows: education aims to create youth's awareness of the future "(futures literacy) [6]. Section "Education for the Future" sets out the main requirements for the process and learning outcome. Education is required to be based on "connectedness", interconnectedness and multidisciplinarity:

- should engage, release creative energy and actively develop adaptive self-learning and mutual help;

- to have value sense, to be based on common ideals and respect for cultural differences;

- to focus on new knowledge and disciplines, in particular ecology, interconnection of systems and sustainable development, which have not yet become part of the common cultural heritage, so teaching relevant knowledge and skills for new generations is essential;

- to cultivate integrated thinking, capable of absorbing, harmonizing and reuniting disparate elements and gaining full realizing fundamental reality;

- to be aware of the multiplicity of a content.

Many high educational establishments popularize well-recognized scientific schools, but should instead "give young minds the full range of contradictory and complementary perspectives" [6]. 


\begin{tabular}{|c|c|c|c|c|c|c|c|c|c|}
\hline Latvia & 43.18 & 34 & $\mathrm{HI}$ & 33 & EUR & 23 & 0.69 & 39 & \\
\hline Malaysia & 43.16 & 35 & UM & 2 & SEAO & 8 & 0.66 & 48 & $\square$ \\
\hline Slovakia & 42.88 & 36 & $\mathrm{HI}$ & 34 & EUR & 24 & 0.74 & 28 & - \\
\hline Bulgaria & 42.65 & 37 & UM & 3 & EUR & 25 & 0.79 & 19 & - \\
\hline United Arab Emirates & 42.58 & 38 & $\mathrm{HI}$ & 35 & NAWA & 3 & 0.50 & 95 & $\square$ \\
\hline Poland & 41.67 & 39 & $\mathrm{HI}$ & 36 & EUR & 26 & 0.69 & 42 & 口 \\
\hline Lithuania & 41.19 & 40 & $\mathrm{HI}$ & 37 & EUR & 27 & 0.63 & 58 & \\
\hline Croatia & 40.73 & 41 & UM & 4 & EUR & 28 & 0.70 & 37 & 口 \\
\hline Greece & 38.93 & 42 & $\mathrm{HI}$ & 38 & EUR & 29 & 0.59 & 74 & \\
\hline Ukraine & 38.52 & 43 & LM & 1 & EUR & 30 & 0.90 & 5 & \\
\hline Thailand & 38.00 & 44 & UM & 5 & SEAO & 9 & 0.71 & 33 & \\
\hline Viet Nam & 37.94 & 45 & LM & 2 & SEAO & 10 & 0.80 & 16 & 들 \\
\hline Russian Federation & 37.90 & 46 & UM & 6 & EUR & 31 & 0.58 & 77 & 두둠 \\
\hline Chile & 37.79 & 47 & $\mathrm{HI}$ & 39 & LCN & 1 & 0.60 & 68 & \\
\hline Moldova, Republic of & 37.63 & 48 & LM & 3 & EUR & 32 & 0.89 & 6 & \\
\hline Romania & 37.59 & 49 & UM & 7 & EUR & 33 & 0.66 & 47 & 夏 \\
\hline Turkey & 37.42 & 50 & UM & 8 & NAWA & 4 & 0.75 & 25 & 둘 \\
\hline Qatar & 36.56 & 51 & $\mathrm{HI}$ & 40 & NAWA & 5 & 0.57 & 81 & - \\
\hline Montenegro & 36.49 & 52 & UM & 9 & EUR & 34 & 0.63 & 56 & \\
\hline Mongolia & 35.90 & 53 & LM & 4 & SEAO & 11 & 0.72 & 30 & $\mathbf{E}$ \\
\hline Costa Rica & 35.72 & 54 & UM & 10 & LCN & 2 & 0.68 & 43 & 口 \\
\hline$\underline{\text { Serbia }}$ & 35.46 & 55 & UM & 11 & EUR & 35 & 0.63 & 57 & \\
\hline Mexico & 35.34 & 56 & UM & 12 & LCN & 3 & 0.59 & 72 & \\
\hline India & 35.18 & 57 & LM & 5 & CSA & 1 & 0.65 & 49 & 1 \\
\hline South Africa & 35.13 & 58 & UM & 13 & SSF & 1 & 0.55 & 83 & \\
\hline Georgia & 35.05 & 59 & LM & 6 & NAWA & 6 & 0.58 & 79 & $\square$ \\
\hline Kuwait & 34.43 & 60 & $\mathrm{HI}$ & 41 & NAWA & 7 & 0.74 & 26 & - \\
\hline Soudi Arabia & 34.27 & 61 & $\mathrm{HI}$ & 42 & NAWA & 8 & 0.47 & 104 & ב \\
\hline Uruguay & 34.20 & 62 & $\mathrm{HI}$ & 43 & LCN & 4 & 0.64 & 51 & \\
\hline Colombia & 33.78 & 63 & UM & 14 & LCN & 5 & 0.50 & 94 & \\
\hline
\end{tabular}

Fig. 1. Resource: the Global Innovation Index

At the Education World Forum, held in London on January 20-23, 2019, the main trend was to integrate the best practices of leading education systems, with the subtitle "What do we do with what we know?" The UK's represented experience in education provided an answer to the question of how relevant it was to consider the achievements of other countries [7]. In the process of reorganization of the educational system they are aimed at: practice of teachers from Shanghai in teaching mathematics, Singapore - in making integrated curriculum, interesting to the learners, charter schools in the US - in the developing practical skills, Germany - in professional education. The UK confirms the effectiveness of such an eclectic "mix" of other countries' practices. The changes began with teachers' retraining, which in its turn helped raise London schools from the lowest grades to the proper ones in the education system. Appropriate financing of education always ensures the profitability of economy, as it is a chance to inspire new generations for creativity and innovation [7].

In the context of our research, the statement of representatives of Cambridge Assessment is relevant. In their view, to make education accessible and effective, three doors need to be opened: teacher, curricula and technology in students hands. And these components are equally important and interrelated [8].

The importance of teacher's role is emphasized by the leadership of the International Student Assessment Program (PISA), the educational direction of the Organization for Economic Cooperation and Development.

This year, they presented the PISA survey and updated the public's involvement in the educational development. For example, what are the components of a highly professional teacher? Firstly, it is the proper knowledge in the field of science (specific discipline, subject), secondly, professional freedom (choice of methods, means, technologies). And thirdly, it is communication with colleagues (experience exchange appeared to be more effective than the period of upgrading). Another issue of considerable interest was the impact of the duration of training on the quality of the results. In fact, there is no such correlation, the panel states and concludes that creativity and critical thinking are important 21 st century skills. The conclusion of the discussion is: "Our task is to grow first-class people, not second-rate robots" [7].

The reform of the educational system of Ukraine in the process of integration into the world academic space is due to the development and implementation of the legislative and regulatory documentation in the educational process of national educational institutions.

The Ministry of Education and Science presented 10 priorities for 2019 in the reform of Ukraine's education system in the context of integration into the world educational space [9]: new mechanisms for teachers' professional development: voluntary certification and the mechanism "money for the teacher"; implementation of the principle "money goes after a teacher" for advanced training; educational ombudsman started working; education digitization: the Internet and computers to rural schools; launching a major vocational education reform: new standards and $€ 58$ million infrastructure project; development of dual education, within which an applicant of education receives theoretical knowledge in the institution of professional education, and the rest - at the real workplace; establishment of the National System of Qualifications: link between the labor market and education; start-up of the National 
Research Fund; commencement of work of centers for collective use of equipment at the institutions of higher education; implementation of science basic funding at higher educational establishments. The current national educational policy confirms the introduction of these areas of innovation into the activities of educational institutions and state institutions.

The line ministry presents innovations [10] that will be implemented in the fields of science, education and innovation in three terms - until the end of 2019 , during 2020 and for the next 5 years.

Among the major changes that are planned to be introduced in the fields of education and science are: development and implementation of the Laws of Ukraine, formation of a network of career advisers for students' vocational guidance; arrangement of laboratories for robotics and STEAM; creation of electronic materials for children from temporary occupied territories (TOT); psychological support for gray area schools and students from TOT; creation of training centers and modern workshops; organization of 7 centers of professional excellence in 7 regions of Ukraine; more short-term adult programs; freedom in professional development; new form of financing for universities is not quantity but quality; launch of the National Research Foundation and the National Depository of Scientific Texts; creation of 7 additional centers for collective use of scientific equipment at higher educational establishments; postdoctoral programs, etc.

These tasks actualize the growth of the professional and pedagogical competence of teachers of higher educational establishments and postgraduate pedagogical educational institutions. Thus, the Model educational program of organization and carrying out teachers' upgrading in postgraduate pedagogical education establishments in the profile of coaches' and teachers' of elementary classes basic competences include the following: andragogic, professional-pedagogical, socio-cuitural, linguistic and communicative, psychological and facilitative, entrepreneurial and information-digital.

In our opinion, the analysis has actualized another important teacher's competence - scientific and methodological, in which we see a multicomponent integralsemantic system of equivalent general philosophical, general scientific and specific scientific competences, realized through the levels, forms of organization and purpose, types of educational architecture, stages of multi-level lifelong learning through integration, mutual use and eclectic diversity of educational technologies, research and innovation theories in teacher training systems; creation of high-tech methodological and research support of the educational process and on the basis of this production of scientific provisions and reasoned results as a result of carrying out researches in a certain branch of science and interbranch ones, which solve complex scientific-theoretical or concrete-practical problems [13].

In order to ensure the process of reforming the educational system, it is important to form the scientific and methodological competence of teachers in postgraduate pedagogical educational institutions, which means, above all, the process of creative self-disclosure of pedagogical and scientific-pedagogical employees' personality, updating their activity, which is revealed through an innovative combination, modernization and updating context, methods and forms of learning with actualization of such factors as openness, self-organization, selfdevelopment, communicativeness, creativity and nonlinearity, critical thinking, control, self-management, self-government, teamwork, etc. [14].

Researches, conducted in the context of today's challenges, related to the outflow of a large number of professionals abroad and decrease in the number of working population, enable to identify the problems of staffing and labor migration, as well as to find ways to prevent its effects.

Thus, creation of training and practical centers, modern workshops, centers of collective use of equipment in higher education institutions and organization of activity of centers of professional excellence in the regions of Ukraine will ensure the satisfaction of employers' needs in training requested professionals in the modern labor market with proper practical experience.

Short-term programs for adults and freedom in advanced training through the flexibility of forms and methods of interdisciplinary-integrated learning will ensure adaptive orientation of the continuous educational system by matching with their own individual educational trajectory in terms of market competition, contents, tenders, demand for constant knowledge generation, skills, competencies for solving production problems through retraining and self-training, their ability to perform increased range of functions and tasks, and thus demand and realization on the internal labor market.

The improvement of the educational regulation system, improvement of the quality of Ukrainian educational services, modernization of educational programs in accordance with market needs and proper logistics of higher educational institutions, on the one hand, will reduce the outflow of young people, who want to study outside Ukraine, on the other hand - will allow to attract students from abroad, which can become an additional source of state income in the form of foreigners' tuition for educational services, as well as the possibility of inflow of labor resources into the domestic economy.

In the practical terms it is necessary to pay attention to such moments as: universities;

- overcoming excess bureaucracy of domestic

- application of up-to-date methods and technologies in the educational and scientific process in higher educational establishments and postgraduate pedagogical educational institutions;

- timely updating of educational programs and standards that should be guided by a competency-based approach;

- modernization of the content of advanced training taking into account individual professional-personal needs and requests of customers of educational services of different qualification categories and specialties;

- transition to a dynamic system of specialists' advanced training, which will enable to satisfy the personality's ability to obtain a certain educational level in a desired specialty in accordance with his/her abilities and to provide mobility on the labor market; 
- creation of a list of informal online resources (both domestic and foreign) that are recommended for self-education and competence development;

- certification of distance learning courses for further inclusion in the list of recommended courses;

- development of technologies of teachers' advanced training during their inter-certification period, creation of optimal conditions for their self-development, self-improvement, self-realization and creation of their own individual educational trajectory in the conditions of continuous education;

- realization of opportunities of dual system of training with use of practitioners (consulting, conducting of workshops, theoretical seminars, practices);

- emphasizing focusing of the heads of state and local self-government bodies on the role of advanced training in the modernization of the system of continuous education in Ukraine and solving the problems of stuffing and labor migration [13].

\section{Conclusions}

1. The research of interstate structures and nonprofit international organizations and foundations has been analyzed, the experience of forming the world educational space in the conditions of cross-border integration has been studied.

2. The world practice of solving educational problems has been considered, the essential characteristics of integration processes for further implementation in the educational process of the national educational system have been revealed.

3. The interim results and current plans of the national line ministry for reforming Ukraine's educational system into the global academic space in the context of lifelong education have been characterized.

4. The problems of human resources and labor migration in the context of contemporary globalization challenges and cross-border integration of Ukraine into the world academic space have been investigated and recommendations for their solution have been given.

\section{References}

1. Ilnytskyi D. O. Hlobalna konkurentsiia v naukovo-osvitnomu prostori: intelektualno-resursnyi vymir: doctor theses. Kyiv, 2016. $512 \mathrm{p}$

2. The Global Competitiveness Report 2017-2018 / World Economic Forum. URL: http://www.weforum.org

3. Ukraina pidnialasia na 7 pozytsii u Hlobalnomu indeksi innovatsii. 2018. URL: https://talks.happymonday. com.ua/ukraina-u-globalnomu-indeksi-innovacij/

4. Human Development Indices and Indicators 2018 Statistical Update. 2018. URL: http://hdr.undp.org/sites/ default/files/2018_human_development_statistical_update.pdf

5. The Global Innovation Index. 2019. URL: https://www.globalinnovationindex.org/home

6. Von Weizsäcker E. U., Wijkman A. Come On! Capitalism, Short-termism. Population and the Destruction of the Planet. Springer, 2018. 220 p. doi: http://doi.org/10.1007/978-1-4939-7419-1

7. The world's largest gathering of education and skills ministers. London, 2019. URL: https://www.theewf.org/

8. Kyselova K. Try innovatsiini trendy, shcho robliat osvitu efektyvnoiu i dostupnoiu. URL: https:/osvitoria.media/opinions/3-innovatsijni-trendy-shho-roblyat-osvitu-efektyvnoyu-i-dostupnoyu/

9. 10 priorytetiv na 2019 rik vid MON. URL: https://www.facebook.com/Osvita.org.ua/posts/2249660868399352/

10. Reforma osvity: u MON rozpovily pro osnovni zminy. URL: https://osvita.ua/news/66739/

11. Tolochko S. Structured system analysis of determination of modern key competences in the world // ScienceRise: Pedagogical Education. 2018. Vol. 5, Issue 25. P. 36-42. doi: http://doi.org/10.15587/2519-4984.2018.139110

12. Tolochko S. Analysis of European Experience in solving modern problems in education and science // ScienceRise: Pedagogical Education. 2018. Vol. 6, Issue 26. P. 9-15. doi: http://doi.org/10.15587/2519-4984.2018.140642

13. Tolochko S. V. Teoretychni y metodychni zasady formuvannia naukovo-metodychnoi kompetentnosti vykladachiv u systemi pisliadyplomnoi pedahohichnoi osvity. Kyiv, 2019. 574 p.

14. Tolochko S. V. Kontseptsiia ta metodyka formuvannia naukovo-metodychnoi kompetentnosti vykladachiv u systemi pisliadyplomnoi pedahohichnoi osvity. Nizhyn: Vyd-vo NDU imeni Mykoly Hoholia, 2019. 376 p.

15. Voitovska O., Tolochko S., Bordyug N. Lifelong Learning in Modern Strategies of Sustainable Development // Studia warmińskie. 2018. Issue 55. P. 343-353. doi: http://doi.org/10.31648/sw.3081

16. Orazbayevaa K. Professional Competence of Teachers in the Age of Globalization // International journal of environmental \& science education. 2016. Vol. 11, Issue 9. P. 2659-2672.

17. Teacher Educator Technology Competencies / Foulger T. S., Graziano K. J., Schmidt-crawford D. A., Slykhuis D. A. // Journal of Technology and Teacher Education. 2017. Vol. 25, Issue 4. P. 413-448.

18. Harits M., Sujadi I., Slamet I. Technological, pedagogical, and content knowledge math teachers: to develop 21st century skills students // Journal of Physics: Conference Series. 2019. Vol. 1321. P. 032011. doi: http://doi.org/10.1088/1742$6596 / 1321 / 3 / 032011$

19. Ouh E. L., Irawan Y. Applying case-based learning for a postgraduate software architecture course // Annual Conference on Innovation and Technology in Computer Science Education, ITiCSE. 2019. P. 457-463.

20. Wagner C., Kawulich B., Garner M. A Mixed Research Synthesis of Literature on Teaching Qualitative Research Methods // SAGE Open. 2019. Vol. 9, Issue 3. doi: http://doi.org/10.1177/2158244019861488

21. Diagnosis of a teacher training programme in competencies for the first year of university / Rivilla A. M., Ruiz-Cabezas A., Navío E. P., Medina Domínguez M. C. // Aula Abierta. 2019. Vol. 48, Issue 2. P. 239-249. doi: http://doi.org/10.17811/ rifie.48.2.2019.239-250

Received date 19.12.2019

Accepted date 28.02.2020

Published date 31.03.2020

SvitlanaTolochko, Doctor of Pedagogical Sciences, Professor, Department of Pedagogy, National University of Life and Environmental Sciences of Ukraine, Heroiv Oborony str., 15, Kyiv, Ukraine, 03041

E-mail: svitlana-tsv@ukr.net 